\title{
3 Measurement of Soil Respiration
}

\author{
H. LANKREIJER, I. JANSSENS, N. Buchmann, B. Longdoz, \\ D. EPRON, S. DORE
}

\subsection{Introduction}

Within terrestrial ecosystems, the soil $\mathrm{CO}_{2}$ efflux is one of the largest carbon flux components. The global efflux of carbon from the soil is estimated between 50 and $75 \mathrm{Gt} \mathrm{C}$ year ${ }^{-1}$ and makes up $20-40 \%$ of the total annual input of carbon dioxide into the atmosphere (Houghton and Woodwell 1989; Raich and Schlesinger 1992; Schimel 1995). The magnitude of the soil flux is similar to that of the net primary productivity (Houghton and Woodwell 1989). It has been suggested that as global temperature rises, enhanced decomposition of the large soil carbon stock $\left(1580 \_10^{15} \mathrm{~g}\right.$; Schimel 1995), especially in the high northern latitudes, might increase the input of carbon into the atmosphere (Gordon et al. 1987; Kirschbaum 1995; Trumbore et al. 1996; Zimov et al. 1996). However, the effect of a temperature increase on the decomposition rate is still unsolved and a point of discussion. Others suggest that decomposition rates in forest soils are not controlled by temperature (Liski et al. 1999; Giardina and Ryan 2000). Besides the potential temperature-induced feedback, changes in land use and forest management, which do affect the storage of carbon in the soil, were important points of discussion throughout the negotiations of the Kyoto protocol. Therefore, understanding the processes underlying the exchange of carbon from and into the soil is needed to make "management of the net carbon budget" possible (IGBP Terrestrial Carbon Working Group 1998).

The efflux of $\mathrm{CO}_{2}$ from the soil originates from different sources. Decomposition of organic matter (heterotrophic respiration) and respiration by living roots (autotrophic respiration) are the two main sources, but chemical oxidation and carbonate dissolution may also contribute to the total flux (Burton and Beauchamp 1994). The contribution of the diverse sources to the total flux is difficult to obtain. Reported estimates of the contribution of root respiration to the total soil $\mathrm{CO}_{2}$ efflux in forests range from 10 to $90 \%$ (Tate et al. 1993; Thierron and Laudelout 1996; Hanson et al. 2000) and an average of $45 \%$ is given by Landsberg and Gower (1997). However, part of the observed

F. Kröner, Heidelberg

Ecological Studies, Vol. 163

R. Valentini (Ed.) Fluxes in Carbon,

Water and Energy of European Forests

(c) Springer-Verlag Berlin Heidelberg 2003 
Ecological Studies Vol 163, page proofs as of September 11, 2002

variability is related to the use of different methodologies (see also Chap. 12, this Vol.).

The efflux of $\mathrm{CO}_{2}$ from the soil is very heterogeneous both in time and space. The high (spatial) variability introduces an uncertainty in the estimation of a mean or a total annual value and is caused by the heterogeneity in soil structure, temperature, soil moisture, bacterial, fungal, and root density distributions, and soil organic matter content. Also, the variability in the transport processes of $\mathrm{CO}_{2}$ from deeper layers to the surface (soil diffusivity), and the turbulence and pressure patterns above the soil contribute to the heterogeneity in the soil $\mathrm{CO}_{2}$ efflux.

Measurements of the rate of $\mathrm{CO}_{2}$ efflux from the soil performed with an hourly or daily time step show high correlation with soil temperature and/or soil moisture content (Janssens et al., Chap. 12). Soil respiration is limited under low and very high soil water contents. Low soil water content may lead to lower quantities of dissolved organic carbon (DOC), which is an important substrate for heterotrophic soil respiration (Billings et al. 1998). Under watersaturated conditions respiration depends strongly on the transport of dissolved gases and can be limited by poor aeration (Freijer and Leffelaar 1996). Heterotrophic respiration is mainly determined by temperature and water content, but also by substrate quality expressed by the concentration of lignin and nitrogen (Ågren and Bosatta 1996b; Ryan et al. 1997). Boone et al. (1998) found that root respiration has even a higher sensitivity to temperature than heterotrophic respiration. They suggested that when plants increase their allocation to the roots under elevated atmospheric $\mathrm{CO}_{2}$ concentration, elevated temperatures lead to lower sequestration of carbon in the soil due to the higher root respiration. This means that autotrophic respiration is also influenced by allocation of carbon assimilates to the roots and the fast turnover of these assimilates. The exact influence of mycorrhizae on soil respiration is not yet known and may be related to the activity of the trees. Taking into account the significant export of carbon assimilates [up to $25 \%$ of net primary production, (NPP)] to the prolific mycorrhizae (100-800 km of living hyphae may be found per gram of soil), the contribution of the mycorrhizae to the soil carbon efflux cannot be neglected (R. Finlay, pers. comm.). Root respiration might be sensitive to the soil $\mathrm{CO}_{2}$ concentrations, and high $\mathrm{CO}_{2}$ concentrations in the soil atmosphere have been described as inhibiting root respiratory activity (Qi et al. 1994; Burton et al. 1997).

The soil $\mathrm{CO}_{2}$ efflux on the short time scales of minutes to days depends not only on the production of $\mathrm{CO}_{2}$ by roots and soil organisms, but also on the transport from the subsurface upward (Fang and Moncrieff 1999a). In the unsaturated soil layers the transport can occur in both the liquid and the gas phase. Diffusion - driven by concentration gradients - is considered to be the primary mechanism, but transport by convection and dispersion may also occur, especially in water-saturated soils (_imùnek and Suarez 1993a; Freijer and Leffelaar 1996). Precipitation, pressure differences, and turbulence above

\section{F. Kröner, Heidelberg}


the soil surface can influence the efflux (Baldocchi and Meyers 1991; Hanson et al. 1993). It is expected that the latter effect is more profound in soil with a thick litter layer and less so in less porous, bare soils. Carbon dioxide stored in the (porous) litter layer exchange faster under conditions of turbulence.

As soil respiration is mainly determined by temperature, its seasonal variability usually tracks the temperature trend over the whole year (Boone et al. 1998). Soil water content might change this picture by limiting soil respiration under dry circumstances, while the contribution of root respiration may also differ strongly throughout the year, depending on growth rates and allocation patterns. In winter, soil respiration rates are usually expected to be low due to low temperatures. However, recent studies report a consistent $\mathrm{CO}_{2}$ flux from forest tundra of $89 \mathrm{~g} \mathrm{C} \mathrm{m}^{-2} \mathrm{~s}^{-1}$ (Zimov et al. 1996) and 2-69 $\mathrm{g} \mathrm{C} \mathrm{m}^{-2} \mathrm{~s}^{-1}$ from tussock tundra during winter (Oechel et al. 1997; Fahnestock et al. 1998). The sources and the control of soil respiration during winter in arctic ecosystems are not well understood (Grogan et al. 2001). The occurrence of soil frost and/or a snow layer may lead to release of carbon in pulses when temperature rises again above zero. Flush of carbon from the decomposition of killed microbes, stimulation of the microbes by higher temperatures, release of $\mathrm{CO}_{2}$ trapped in ice, or accumulation of $\mathrm{CO}_{2}$ under the snow are considered causing those often observed flushes of carbon dioxide (Billings et al. 1998).

\subsubsection{Measuring Soil Respiration}

Considering the complexity of processes behind the $\mathrm{CO}_{2}$ efflux from the soil, its heterogeneity in both space and time, and the interactions with the forest canopy above the soil, an estimate of the total $\mathrm{CO}_{2}$ efflux from the soil and its components is not easy to obtain.

Many commercially available or self-made systems are used to measure soil respiration rates directly at the soil level (Norman et al. 1997; Janssens et al. 2000), and several different systems were applied at the EUROFLUX sites. The most common technique is to place a chamber on the soil surface and measure the change in $\mathrm{CO}_{2}$ concentration in it. An advantage of the chamber system is the relative easy application and straightforward approach. Soil $\mathrm{CO}_{2}$ efflux can also be estimated from measurements of the $\mathrm{CO}_{2}$ concentration profile in or above the soil (e.g., Zimov et al. 1996). The advantage of profile measurements in the soil is the possibility of thus estimating the source depth of the flux, but the disadvantage is the difficulty in estimating soil and air diffusivity. The aboveground profile measurements are easier to perform, but when the difference in $\mathrm{CO}_{2}$ concentration along the vertical axis is small, errors are large.

The eddy covariance method applied directly above the forest soil has several advantages over chamber-based methods and is probably the most suitable method: (1) the soil surface and soil microclimate are not disturbed, (2)

F. Kröner, Heidelberg 
Ecological Studies Vol 163, page proofs as of September 11, 2002

measurements are performed under "natural" turbulent conditions, and (3) a larger surface area is covered. The technique requires sufficient turbulence below the canopy (Baldocchi et al. 1997) and no other sources and sinks between the soil surface and the sensor. Above-canopy eddy flux measurements also include, besides soil respiration, the respiration and photosynthesis of the vegetation. Total ecosystem respiration from both the soil and the vegetation can be derived from eddy flux measurements above the canopy from night-time flux extrapolation or by analysis of the daytime measurements (see Chap. 8, Falge et al.). However, distinction between respiration from the soil and from the vegetation above the ground is not possible with these methods, without using empirical estimates, and when both storage during stable conditions and advection of the carbon flux exist on the site, correction of the night-time fluxes is needed.

\subsubsection{Modeling}

Estimates of soil carbon fluxes by simulation models have been used in numerous studies. Many simulation studies focus, however, on the decomposition of organic matter in the soil (Ågren and Bosatta 1987, 1996a; Jenkinson 1990, 1991; Liski 1997) and describe the change in the storage of carbon in the soil. In spite of its importance, the simulation of the soil carbon efflux by process-based models including both heterotrophic and autotrophic respiration has been rather limited (_imùnek and Suarez 1993a; Freijer and Leffelaar 1996; Fang and Moncrieff 1999a). In general, predictive models have used regression functions fitting the $\mathrm{CO}_{2}$ flux to environmental parameters (Hanson et al. 1993; Lloyd and Taylor 1994; Peterjohn et al. 1994; Lavigne et al. 1997). Regression of the $\mathrm{CO}_{2}$ efflux by soil temperature and humidity typically results in $\mathrm{r}^{2}$ values above 0.7 , but still does not explain the total variance in the efflux (see Chap. 12, this Vol.). This shortcoming can be partly attributed to the lack of a detailed description of the production and transport processes as well as to the use of inaccurate techniques for measuring soil $\mathrm{CO}_{2}$ efflux. Factors such as root/mycorrhizal activity, atmospheric turbulence, substrate "quality" (Ågren and Bosatta 1996b), soil structure, and diffusivity might be important, but are more difficult to assess. Seasonal variations can be described and simulated quite well, whereas the reasons for spatial variations are still poorly understood.

Using only average air temperature may be sufficient for simulating longterm decomposition of soil organic matter, but is less suited for analyzing short-term processes. The simulation of long-term carbon efflux (on monthly or longer time scales) based on the decomposition rates has been performed by, e.g., Hyvönen et al. (1996) and Liski (1997). Models based on the concept of humus quality show promising results (Bosatta and Ågren 1999; Joffre et al. 2001).

\section{F. Kröner, Heidelberg}




\subsection{Soil $\mathrm{CO}_{2}$ Efflux Measurements in the EUROFLUX Project}

To obtain and analyze the total gain and losses of carbon from forest ecosystems and its compartments, soil respiration was measured at all EUROFLUX sites. Results of the soil respiration measurements within EUROFLUX are presented and discussed in Chapter 12.

The applied techniques for estimation of the soil respiration differ between sites. If the estimation of the soil respiration from eddy flux measurements above the canopy is not considered here, there were 13 different systems for measuring soil respiration (Table 3.1). Most of the systems used a chamber placed at the soil surface. All systems measured the soil efflux without making specific distinction between decomposition and biomass respiration. Several systems included the photosynthesis and respiration of the forest floor vegetation. Roughly, the measurements could be divided into either "continuous" or "periodic" with a certain time interval. The continuous systems measured with a time resolution of 10-30 min, and were used at ten sites. At four of those sites, measurements were performed during the entire year with two to five chambers, while at the other sites the continuous measurements were performed during campaigns. The eddy covariance and profile techniques were used during campaigns at five sites. At 14 of the 18 EUROFLUX sites, soil respiration was measured at intervals with a mobile chamber system. Data collected with the periodic systems represent point measurements with a time resolution varying between 8 and 45 days. At some sites the data are limited to just a few days or nights, but at several sites multiple years of data are available (Table 3.1).

\subsubsection{Chamber Systems}

Depending on the presence or absence of air circulation through chamber and analyzer, chamber techniques have been categorized as either static or dynamic (Witkamp and Frank 1969). Static chamber techniques are based either on enrichment or absorption of $\mathrm{CO}_{2}$ in the headspace. The alkali solution method (Lundegårdh 1927) is probably the oldest method, while the soda lime method (Monteith et al. 1964; Howard 1966; Edwards 1982; Grogan 1998) is probably the most frequently used technique because it is inexpensive, easy to use, and particularly suitable where spatial variation is large (Kleber and Stahr 1995; Keith et al. 1997; Janssens and Ceulemans 1998). However, static techniques tend to be less accurate than dynamic systems due to effects on the diffusion process (Nay et al. 1994; Janssens et al.2000), and are therefore often regarded as inferior to dynamic chamber systems (Norman et al. 1992). Measurements can be improved if they are compared to other measurements (Janssens and Ceulemans 1998).

F. Kröner, Heidelberg 
Ecological Studies Vol 163, page proofs as of September 11, 2002

Table 3.1. Soil respiration measurements. See text for the description of the systems. The frequency gives the interval between the measurements, while the number represents the number of locations measured. Under remarks the number of days with data is given, or how often a reading was taken during a day

\begin{tabular}{|c|c|c|c|c|c|c|}
\hline Site & System & Frequency & Number & Period & Remarks & References \\
\hline \multicolumn{7}{|c|}{ Periodic } \\
\hline $\begin{array}{l}\text { IT1 } \\
(2000)\end{array}$ & $\mathrm{PP}$ & 8-45 days & $15-30$ & $96 / 5-98 / 11$ & 34 days & Matteucci et al. \\
\hline IT2 & $\mathrm{PP}$ & 15-20 days & 30 & $96-98 / 6$ & & Dore (1999) \\
\hline FR1 & $\mathrm{L} 2$ & 14-28 days & 72 & $96 / 6-98 / 10$ & 28 days & $\begin{array}{l}\text { Epron et al. } \\
\text { (1999a); Le } \\
\text { Dantec et al. } \\
\text { (1999) }\end{array}$ \\
\hline SW1 & $\mathrm{L} 2$ & $1 \times$ year & 36 & $97-98$ & Summer & \\
\hline SW2 & L2 & 14 days & 24 & $97 / 5-99 / 10$ & & $\begin{array}{l}\text { Widén and } \\
\text { Majdi (2000) }\end{array}$ \\
\hline GE1 & $\mathrm{L} 4$ & $1 \times$ month & 20 & $98 / 3-98 / 10$ & $1-2 \mathrm{x}$ days & $\begin{array}{l}\text { Buchman } \\
(2000)\end{array}$ \\
\hline GE2 & OG & $1-2 \times$ month & 3 & $98 / 6-98 / 10$ & & \\
\hline NE1 & $\mathrm{PP}$ & 2 nights & 20 & 97 & & \\
\hline BE1 & LH & 14 days & 15 & $97 / 8-98 / 8$ & 40 days & $\begin{array}{l}\text { Longdoz et al. } \\
(2000)\end{array}$ \\
\hline BE2 & $\mathrm{PP}$ & & & $96 / 4-98 / 2$ & $\begin{array}{l}\text { Combined } \\
\text { with SL }\end{array}$ & $\begin{array}{l}\text { Janssens et al. } \\
(2000)\end{array}$ \\
\hline BE2 & SL & 3-4 weeks & 47 & $96 / 4-98 / 2$ & & $\begin{array}{l}\text { Janssens and } \\
\text { Ceulemans } \\
\text { (1998) }\end{array}$ \\
\hline FI1 & SC, SP & $1-2$ weeks & 3 & $97-99$ & & $\begin{array}{l}\text { Ilvesniemi and } \\
\text { Pumpanen } \\
\text { (1997); } \\
\text { Pumpanen et } \\
\text { al. (2001) }\end{array}$ \\
\hline FI1 & SC & $3 \times$ & 10 & $97-99$ & Summer & \\
\hline EX1 & $\mathrm{PP}$ & $1 \times$ month & 10 & $98 / 3-98 / 12$ & $4 \mathrm{x}$ day & \\
\hline EX3 & LH & $1 \times$ month & 4 & $99 / 5-99 / 10$ & & \\
\hline IS1 & L2 & $4-5 \times$ & $44 ; 48$ & $96 ; 97$ & Summer & \\
\hline \multicolumn{7}{|c|}{ Continuous } \\
\hline FR2 & EC & & & $\begin{array}{l}2 \text { months } 1997 \\
16 \text { days } 1998\end{array}$ & & \\
\hline DK1 & DC & $12 \mathrm{~min}$ & $5(10)$ & $96 / 6 ; 96 / 9 ; 97 / 5$ & $1-6$ weeks & \\
\hline DK1 & DC & $12 \min$ & $5(10)$ & $98 / 4-99$ & Year-round & \\
\hline SW1 & OS & $10 \mathrm{~min}$ & $1(2)$ & $97-98$ & 3-4 days & \\
\hline SW2 & OS & $10 \mathrm{~min}$ & $3(20)$ & 95-present & Year-round & $\begin{array}{l}\text { Iritz et al. } \\
\text { (1997); Widén } \\
\text { and Lindroth } \\
(2002)\end{array}$ \\
\hline FI1 & $\mathrm{OC}$ & $30 \mathrm{~min}$ & 2 & $97 / 10-99 / 5$ & Year-round & \\
\hline EX2 & $\mathrm{P}, \mathrm{OC}$ & $15 \mathrm{~min}$ & 2 & $96 / 6-99 / 7$ & Year-round & \\
\hline NE1 & $\mathrm{P}$ & $30 \mathrm{~min}$ & & 96/6-present & Year-round & \\
\hline BE2 & EC & $30 \mathrm{~min}$ & & $98 / 7$ & 11 days; 6 ni & shts \\
\hline GE1 & $\mathrm{EC}$ & $30 \mathrm{~min}$ & & & & \\
\hline
\end{tabular}

\section{F. Kröner, Heidelberg}


Ecological Studies Vol 163, page proofs as of September 11, 2002

Measurement of Soil Respiration

Dynamic chamber systems typically use an infrared gas analyzer (IRGA). Two approaches can be distinguished: closed and open dynamic systems. In closed chamber IRGA systems, air circulates in a loop between the chamber and an external IRGA, and the change in $\mathrm{CO}_{2}$ concentration over time is measured (Parkinson 1981; Norman et al. 1992; Goulden and Crill 1997; Rochette et al. 1997). In open systems, air does not circulate in a loop but is vented to the atmosphere. Open chamber systems have a constant airflow through the chamber, and the difference in $\mathrm{CO}_{2}$ concentrations of the ambient and internal air at the inlet and the outlet are continuously monitored (Witkamp and Frank 1969; Edwards and Sollins 1973; Kanemasu et al. 1974; Schwartzkopf 1978; Denmead 1979; Fang and Moncrieff 1996; Iritz et al. 1997; Rayment and Jarvis 1997).

The classic closed-static, soda lime technique (SL) was applied at the Belgian site Brasschaat (BE2). Another closed-static technique, which made use of manual syringe sampling from a closed soil chamber (SC), was used at the Finish site Hyytiäla (FI1). According to Janssens et al. (2000), the corrected soda lime measurements agreed well with measurements acquired with the portable closed-dynamic system of PP systems (Hitchin, UK) $\left(\mathrm{PP}^{*}\right)$. This last system consists of a CIRAS-1 or EGM-1 infrared gas analyzer and a cylindrical soil chamber (the SRC-1). The PP-system soil respiration set (Parkinson 1981) was used at five sites. The comparable closed-dynamic system by $\mathrm{Li}$ Cor, the Li-Cor 6200 and Li-Cor 6400 gas analyzers (Li-Cor; Li-Cor 1993) combined with the Li 6000-09 or Li 6400-09 soil chambers (L2, L4), was also used at five sites, while the sites at Gembloux (BE1) and Bíl_ Køí_(EX3) used the same type of IRGA, but with home made chambers (LH) based on the same technique, as described by Norman et al. (1992). Use of the portable closeddynamic systems at a total of 11 sites makes it the most commonly used technique within EUROFLUX for direct measurement of the soil $\mathrm{CO}_{2}$ efflux.

The portable, closed-dynamic systems usually resulted in periodic measurements with a long time interval, but with a relative high number of spa-

* The abbreviations are used in Table 3.2

Table 3.2. Range of measured fluxes in $\mu \mathrm{mol} \mathrm{m} \mathrm{m}^{-2} \mathrm{~s}^{-1}$. Measurements were performed over 3 days and averages are shown for each day, if available

\begin{tabular}{lllll}
\hline System & Range & Average day 1 & Average day 2 & Average day 3 \\
\hline LH BE1 & $2-6$ & 4.8 & 3.0 & \\
L2 SE2 & $1.5-6$ & 2.5 & 3.0 & \\
PP BE2 & $3-11$ & 5.5 & 4.0 & 1.6 \\
GE-open & $1-3$ & & & \\
UK-open & $1.6-3.4$ & 2.6 & 1.9 & \\
SE-Lab & $0.5-1.5$ and 2-3 & & & \\
OS SE2 & $1-50$ & & & \\
\hline
\end{tabular}

F. Kröner, Heidelberg 
Ecological Studies Vol 163, page proofs as of September 11, 2002

tially distributed measurements. Based on the same principle as the closeddynamic system, automatic soil chambers (OC) were used at the Sollingen site in Germany (EX2) and Hyytiäla in Finland (FI). Rain and temperature fluctuations reached the soil normally since the chambers were open between the measurements. Readings were almost continuous, however, with a low spatial distribution.

The open-dynamic chambers were all non-commercial home-built systems, mainly developed to obtain continuous readings of the soil carbon efflux. At the Danish site Lille Boegeskov the system consisted of five simultaneously operating chambers (DC). Each chamber covered an area of $28 \times$ $28 \mathrm{~cm}$. The chambers were closed for $25 \mathrm{~min}$ of each hour, but were left open during rainfall. The Swedish open system (OS) consisted of a tunnel-shaped chamber, covering an area of $200 \times 30 \mathrm{~cm}$, and having a continuous flow of air through the system by a fan. The $\mathrm{CO}_{2}$ flux was obtained by measuring the difference between the inlet and outlet concentration of the air with a gas analyzer (IRGA LI-6262, Li-Cor). At the German site Tharandt, the system (OG) consisted of three chambers of $30 \times 35 \mathrm{~cm}$ where the change in $\mathrm{CO}_{2}$ concentration was determined non-differentially and compared to a reference reading of ambient air just before the measurements.

\subsubsection{Meteorological and Profile Gradient Systems}

\subsubsection{Eddy Correlation Below the Canopy (EC)}

At the French site (FR2) a 3-D Gill anemometer type R2, and an "open path" IRGA was used (Advanet E009, the "Otahki" devices), both $6 \mathrm{~m}$ above ground surface. Corrections according to Webb et al. (1980) for open path systems were made on turbulent fluxes. At the Belgian site in Brasschaat (BE2) the equipment consisted of a sonic anemometer (USAT-3, Metek, Germany) and a Li-6262 (Janssens et al. 2000). The anemometer was mounted at a height of $1.65 \mathrm{~m}$ above the forest floor.

\subsubsection{Flux Profile Measurements (P)}

At the Dutch site Loobos the net carbon exchange was estimated from below canopy $\mathrm{CO}_{2}$ concentration profiles measured with a gas analyzer of PP systems. The profile had five levels and measurements were averaged over $5 \mathrm{~min}$ at each level, resulting in a profile for every $30 \mathrm{~min}$. At the German site in Solling (EX2), both the soil chambers and the profile measurements were connected to the same gas analyzer (Li-Cor 6251). Each measurement cycle of 15 min consisted therefore of measured fluxes from two chamber-plots and a profile from several levels within the forest canopy. At the French site Le Bray

\section{F. Kröner, Heidelberg}


Ecological Studies Vol 163, page proofs as of September 11, 2002

Measurement of Soil Respiration

(FR2) profile measurements were made at ten levels between 0.1 and $25 \mathrm{~m}$, with a particular emphasis on the lower levels to catch the night-time storage (levels $0.1,0.2,0.6,0.9$, and $2.0 \mathrm{~m}$ ).

\subsubsection{3 $\mathrm{CO}_{2}$ Profile in the Soil (SP)}

At the Finnish site Hyytiäla the $\mathrm{CO}_{2}$ profile in the soil was measured by manual sampling from tubes installed at different depths in the soil (Ilvesniemi and Pumpanen 1997), while in the winter of 1997/1998 the $\mathrm{CO}_{2}$ concentration profile of the snow was measured once a month.

\subsubsection{Additional Soil Measurements}

Soil temperature, soil water content, and soil texture/density were measured at all sites, generally at the same time that soil respiration rates were measured. Further ancillary data included measurements of $\mathrm{C}$ and $\mathrm{N}$ content of the upper horizons, litter layer thickness, root-biomass distribution, litter decomposition rates, soil temperature profiles, air temperature and humidity just above the soil surface, radiation at the soil level, and atmospheric pressure. These measurements differed in frequency and methodology among the sites and a description of the different techniques is not included here.

\subsection{Comparison of Systems}

Results from in situ comparisons of systems are still limited (Norman et al. 1997). Within the EUROFLUX framework direct comparison of different systems was performed at several sites (Le Dantec et al. 1999; Janssens et al. 2000; Longdoz et al. 2000). Comparison of seven systems was performed during a special organized workshop in Uppsala (Sweden) in June 1997. The systems involved in this experiment were the PP Systems (PP), Li-6200 (L2 and LH), and the Swedish open chamber (OS). Those four systems, applied at the EUROFLUX sites, were also compared to three techniques that were not used at the EUROFLUX sites: two automatic open-dynamic chamber systems, abbreviated as UK-open (Fang and Moncrieff 1996) and GE-open (Kutsch 1996), and one based on $\mathrm{CO}_{2}$ accumulation rates from soil samples incubated at constant temperature (Persson et al. 1989). To create quasi-controlled conditions a container $(4 \times 4 \mathrm{~m})$ was filled with a $30-\mathrm{cm}$-thick layer of (bare) organic soil. However, the spatial variability of the flux of $\mathrm{CO}_{2}$ was still large. During a measurement session prior to the site comparisons, the flux showed an average of $2.87 \mu \mathrm{mol} \mathrm{m}^{-2} \mathrm{~s}^{-1}$ and an SD of $0.77 \mu \mathrm{mol} \mathrm{m}^{-2} \mathrm{~s}^{-1}(\mathrm{CV}=26.5 \%)$.

F. Kröner, Heidelberg 
Ecological Studies Vol 163, page proofs as of September 11, 2002

Thus direct comparison of systems required either measurement at the same location, one after another, or a high number of measurements by each system spread over the entire container. Direct comparison of the portable chamber systems on exactly the same spot revealed the problem of soil disturbance when placing the chambers, either by such placement on the soil or by movement of the collar. This observation made it clear that field measurements with portable chambers, even if using prefixed collars, also have to be performed carefully to avoid pulses of high $\mathrm{CO}_{2}$. Further comparison of systems was therefore restricted to the daily means obtained by each system. The ranges of measured effluxes from 2.5 days are given in Table 3.2.

In general, the open systems from the UK and Germany (UK-open and GEopen) gave lower fluxes than the closed chamber systems (PP, L2, and LH). Of the three closed chamber systems, the PP system systematically gave the highest average value, supporting results reported by Le Dantec et al. (1999) and Janssens et al. (2000). The ventilation fan inside this system might be the reason for the higher measured flux. Direct comparison of both systems, under field and laboratory conditions, showed that the internal wind speed in the chamber as well as the difference between inside and outside wind speed are important factors (Le Dantec et al. 1999). Another reason behind the overestimation of the flux was the use of the EGM-1 analyzer. At that time, this analyzer did not separate IR absorption by $\mathrm{CO}_{2}$ and water vapor, and because of the rather wet soil, both the $\mathrm{CO}_{2}$ and water efflux was measured. As could be expected from a static technique, fluxes estimated with the accumulation technique (SE-Lab) resulted in the lowest values. The Swedish chamber system (OS) showed a high range with values up to five times higher than the other systems. This high efflux of $\mathrm{CO}_{2}$ may be related to the fact that this system uses a transparent chamber; solar radiation could heat up the soil surface. When the chamber was covered by dark plastic, the measured flux rates decreased considerably. Testing the portable Li-6200 (L2) with transparent collars of $10 \mathrm{~cm}$ height also showed higher flux rates. Selection of chamber design (transparent or opaque) should be carefully considered and is an important factor when soil respiration measurements of different sites and systems are compared with each other.

Differences between methodologies for measuring soil $\mathrm{CO}_{2}$ were discussed at the LESC workshop 6-8 April 2000 in Edinburgh, Scotland (Rayment 2000). The workshop resulted in a list with guidelines and recommendations concerning measurements with the different (chamber) systems. Although none of the systems were rejected, and each system has its advantages, all methodologies have to be cross-calibrated and carefully applied. If chambers are used, the open dynamic system is assumed to be the most reliable system. Chambers should be either removed between the measurements or opened between the readings to limit the alteration of the soil.

\section{F. Kröner, Heidelberg}


Ecological Studies Vol 163, page proofs as of September 11, 2002

Measurement of Soil Respiration

\subsection{Discussion}

Based on experience with the large number of different systems applied within EUROFLUX, a number of general problems with the interpretation of the soil respiration estimates can be identified. The main problem is that most systems are not "cross-calibrated" (Rayment and Jarvis 1997)., Such calibrations have been performed up to now on a limited scale and, to date, there is no standard method for measurement of soil respiration (Nay et al. 1994; Conen and Smith 2000; Widén and Lindroth 2002). Janssens et al. (2000) found that measurements performed with the PP system and the Li-Cor chamber systems showed a high correlation, indicating that calibration against a standard system is possible.

Each technique has its specific time and space resolution. Integration of measured fluxes over large areas is hampered by the high heterogeneity in the soil, resulting in highly varying $\mathrm{CO}_{2}$ efflux rates. For chamber techniques this means that a high number of replicates at different spots is required. In order to analyze the processes underlying the flux and to separate the total flux into different components, multiple techniques are needed.

A disadvantage of all systems, except for the meteorological techniques, is that they enclose a part of the soil surface and exclude the effect of turbulence and pressure fluctuations on the soil $\mathrm{CO}_{2}$ efflux. The effect of turbulence is probably the most underestimated factor, since strong gusts of wind as well as long undisturbed stable conditions exist inside the canopy. Thus, how the chamber influences the efflux of carbon dioxide from the soil and its internal flow makes the interpretation of the measurements complicated. On the other hand, fans inside chambers generating the necessary air-mixing may induce an unnatural turbulence, which might result in an increased efflux of $\mathrm{CO}_{2}$ from the soil that can be sustained by enhanced lateral diffusion (Le Dantec et al. 1999; Janssens et al.2000). Only for the closed-dynamic chamber used at the EX2 site in Sollingen, was a correction term mentioned as rectifying the possible error.

Open chamber systems are extremely sensitive to pressure differences between the chamber and the atmosphere (Kanemasu et al. 1974; Fang and Moncrieff 1996; Rayment and Jarvis 1997; Lund et al. 1999). Several approaches have been suggested to minimize these pressure differences, such as simultaneously blowing and drawing air through the chamber (Fang and Moncrieff 1996), and the use of very large air inlet apertures (Iritz et al. 1997; Rayment and Jarvis 1997), but elimination of pressure gradients is still a problem with today's systems. In closed systems, pressure equilibration between the chamber and the atmosphere can be achieved with a properly designed venting tube (Hutchinson and Mosier 1981; Norman et al. 1992), through which leakage can be restricted to a minimum.

All chamber techniques have the potential problem of disturbance of the respiratory processes by the technique itself, i.e., the chamber (Nay et al. 1994;

F. Kröner, Heidelberg 
Lund et al. 1999; Conen and Smith 2000). When forest floor vegetation is enclosed in the chamber, plant respiration is included in the measurements, which makes distinction of the fluxes difficult. Further, when the chamber is transparent for light, the measured flux can include the uptake of $\mathrm{CO}_{2}$ by photosynthesis.

The eddy covariance technique applied below the canopy is probably a very suitable method for measuring the $\mathrm{CO}_{2}$ from the soil as the natural distribution of the vertical pressure gradient, the horizontal air velocity, and the vertical $\mathrm{CO}_{2}$ concentration gradient are not disturbed (Longdoz et al.2000). However, the conditions for using this technique are not always suitable - for example, in young and low forest stands when a sink of carbon exists between the soil and the sensor. Eddy flux measurements cover a relative large area under the canopy. Comparison of below canopy eddy flux measurements with chamber measurements has to take these conditions in to account, but have shown good agreement (Law et al. 1999; Matteucci et al. 2000; Janssens et al. 2001).

Major advantages of continuous chamber systems are availability of series of data over a long period of time and measurement under relatively undisturbed conditions. However, usually the number of monitored locations with continuous measuring systems is low, thus limiting their potential for scaling in space. In addition, with time, the conditions within some of the continuous systems might differ strongly from the surroundings, again limiting their use for extrapolation.

Advantages of the mobile chamber systems are (1) no permanent power requirements, and (2) a potential for covering large areas and accounting for great spatial variations. Chamber measurements are more useful for distinguishing the spatial distribution and contribution of different sources at the soil surface. However, portable chamber measurements have to be performed carefully, considering the potential disturbances when no preinstalled collars are used; and when collars are used, it is often difficult to determine to what depth they can be inserted without disturbing roots.

Separation of heterotrophic and autotrophic soil respiration, and in some cases respiration of the aboveground biomass, is not possible with any of the systems described above. Within the EUROFLUX project, root respiration was estimated by comparing efflux measurements from root-free plots and control plots (Epron et al. 1999b; Janssens 1999). Other techniques for separating root from microbial respiration, which have been applied elsewhere, are using root cuvettes in the field (e.g. Gansert 1994; Ryan et al. 1996), excavating and directly measuring in a closed chamber in the field (Widén and Majdi 2000), excising roots in the laboratory (Burton et al. 1998), trenching (Bowden et al. 1993; Fisher and Gosz 1986; Boone et al. 1998; Hart and Sollins 1998), girdling of trees (Högberg et al. 2001), performing ${ }^{14} \mathrm{C},{ }^{13} \mathrm{C}$, or ${ }^{18} \mathrm{O}$ studies (Horwath et al. 1994; Swinnen et al. 1994; Högberg and Ekblad 1996; Lin et al. 1999; Högberg et al. 2001), inhibiting one respiratory component with specific

\section{F. Kröner, Heidelberg}


inhibitors or herbicides (Helal and Sauerbeck 1991; Nakane et al. 1996), applying a controlled accumulation technique in the laboratory (Persson et al. 1989), and enhancing one component over the other (Bowden et al. 1993). Lin et al. (1999) used stable isotopes, but their system was strongly influenced by the tank $\mathrm{CO}_{2}$ with a very different carbon isotopic composition compared to ambient $\mathrm{CO}_{2}$. Isotopes have to be measured frequently if partitioning between microbial and root respiration is the objective, since activities change so fast seasonally.

\subsection{Conclusions}

Despite its long history of measurements, the process of soil respiration remains difficult to assess and to interpret. As there is not yet one preferable system applicable and suitable for all environmental conditions and ecosystems, a careful comparison with other techniques and a thorough analysis of potential effects of the applied technique on the flux itself is needed whenever soil respiration is measured. Based on the experiences within EUROFLUX, a system that causes no or only small changes in the environmental conditions (inside the chambers) has to be used for a correct assessment of the actual soil respiratory fluxes. Spatial and temporal variability has to be accounted for by an adequate sampling design.

In order to be able to explain the measured flux, determination of the soil temperature, soil water content, soil carbon/organic matter content and distribution, fine root biomass and distribution, soil texture, and litter-layer thickness and nutrient content need to be included in the measurement program.

\section{References}

Ågren GI, Bosatta E (1987) Theoretical analysis of long-term dynamics of carbon and nitrogen in soils. Ecology 68:1181-1189

Ågren GI, Bosatta E (1996a) Theoretical ecosystem ecology; understanding element cycles. Cambridge Univ Press, Cambridge, 234 pp

Ågren GI, Bosatta E (1996b) Quality: a bridge between theory and experiment in soil organic matter studies. Oikos 76:522-528

Aubinet M, Grelle A, Ibrom A, Rannik U, Moncrieff J, Foken T, Kowalski AS, Martin P, Berbigier P, Bernhofer C, Clement R, Elbers I, Granier A, Gruenwald T, Morgenstern K, Pilegaard K, Rebmann C, Snijders W, Valentini R, Vesala T (2000) Estimates of the annual net carbon and water exchange of European forests: the EUROFLUX methodology. Adv Ecol Res 30:113-175

Baldocchi DD, Meyers TP (1991) Trace gas exchange above the floor of a deciduous forest. 1. Evaporation and $\mathrm{CO}_{2}$ efflux. J Geophys Res 96(D4):7271-7285

F. Kröner, Heidelberg 
Baldocchi DD, Vogel CA, Hall B (1997) Seasonal variation of carbon dioxide exchange rate above and below a boreal jack pine forest. Agric For Meteorol 83:147-170

Billings SA, Richter DD, Yarie J (1998) Soil carbon dioxide fluxes and profile concentrations in two boreal forests. Can J For Res 28:1773-1783

Bonan GB (1992) Physiological controls of the carbon balance of boreal forest eceosystems. Can J For Res 23:1453-1471

Boone RD, Nadelhoffer KJ, Canary JD, Kaye JP (1998) Roots exert a strong influence on the temperature sensitivity of soil respiration. Nature 396:570-572

Bosatta E, Ågren GI (1999) Soil organic matter quality interpreted thermodynamically. Soil Biol Biochem 31:1889-1891

Bowden RD, Nadelhoffer KJ, Boone RD, Melillo JM, Garrison JB (1993) Contributions of aboveground litter, belowground litter, and root respiration to total soil respiration in a temperate mixed hardwood forest. Can J For Res 23:1402-1407

Buchmann N (2000) Biotic and abiotic factors modulating soil respiration rates in Picea abies stands. Soil Biol Biochem 32:1625-1635

Burton DL, Beauchamp EG (1994) Profile nitrous oxide and carbon dioxide concentrations in a soil subject to freezing. Soil Sci Soc Am J 58:115-122

Burton AJ, Zogg GP, Pregitzer KS, Zak DR (1997) Effect of measurement $\mathrm{CO}_{2}$ concentration on sugar maple root respiration. Tree Physiol 17:421-427

Burton AJ, Pregitzer KS, Zogg GP, Zak DR (1998) Drought reduces root respiration in sugar maple forests. Ecol Appl 8:771-778

Conen F, Smith KA (2000) An explanation of linear increases in gas concentration under closed chamber used to measure gas exchange between soil and the atmosphere. Eur J Soil Sci 51:111-117

Denmead OT (1979) Chamber systems for measuring nitrous oxide emission from soils in the field. Soil Sci Soc Am J 43:89-95Dore S (1999) Functional characteristics of carbon balance and energy use in forest ecosystems: comparison between three study cases. PhD Thesis. Universita degli Studi di Padova (in Italian)

Edwards NT (1982) The use of soda-lime for measuring respiration rates in terrestrial ecosystems. Pedobiologia 23:231-330

Edwards NT, Sollins P (1973) Continuous measurement of carbon dioxide evolution from partitioned forest floor components. Ecology 54:406-412

Epron D, Farque L, Lucot E, Badot P-M (1999a) Soil $\mathrm{CO}_{2}$ efflux in a beech forest: the dependence on soil temperature and soil water content. Ann For Sci 56:221-226

Epron D, Farque L, Lucot E, Badot P-M (1999b) Soil $\mathrm{CO}_{2}$ efflux in a beech forest: the contribution of root respiration. Ann For Sci 56:289-295

Fahnestock JT, Jones MH, Brooks PD, Walker DA, Welker JM (1998) Winter and early spring $\mathrm{CO}_{2}$ efflux from tundra communities of northern Alaska. J Geophys Res 103:29023-29027

Fang C, Moncrieff JB (1996) An improved dynamic chamber technique for measuring $\mathrm{CO}_{2}$ efflux from the surface of soil. Funct Ecol 10(2):297-305

Fang C, Moncrieff JB (1999a) A model for soil $\mathrm{CO}_{2}$ production and transport 1: model development. Agric For Meteorol 95:225-236

Fang C, Moncrieff JB (1999b) A model for soil $\mathrm{CO}_{2}$ production and transport 2: application to a Florida Pinus elliotte plantation. Agric For Meteorol 95:237-256

Fisher FM, Gosz JR (1986) Effects of trenching on soil processes and properties in a New Mexico mixed-conifer forest. Biol Fertil Soils 2:35-42

Freijer JI, Leffelaar PA (1996) Adapted Fick's law applied to soil respiration. Water Resour Res 32(4):791-800

Gansert D (1994) Root respiration and its importance for the carbon balance of beech seedlings (Fagus sylvatica L.) in a montane beech forest. Plant Soil 167:109-119

\section{F. Kröner, Heidelberg}


Ecological Studies Vol 163, page proofs as of September 11, 2002

Measurement of Soil Respiration

Giardina CP, Ryan MG (2000) Evidence that decomposition rates of organic carbon in mineral soil do not vary with temperature. Nature 404:858-861

Gordon AM, Schlentner RE, Van Cleve K (1987) Seasonal patterns of soil respiration and $\mathrm{CO}_{2}$ evolution following harvesting in the white spruce forests of interior Alaska. Can J For Res 17:304-310

Goulden ML, Crill PM (1997) Automated measurements of $\mathrm{CO}_{2}$ exchange at the moss surface of a black spruce forest. Tree Physiol 17:537-542

Goulden ML, Munger JW, Fan S-M, Daube BC, Wofsy SC (1996) Exchange of carbon dioxide by deciduous forest: response to inter-annual climate variability. Science 271:1576-1578

Grogan P (1998) $\mathrm{CO}_{2}$ flux measurements using soda lime: correction for water formed during $\mathrm{CO}_{2}$ absorption. Ecology 79:1467-1468

Grogan P, Illeris L, Michelsen A, Johasson S (2001) Respiration of recently-fixed plant carbon dominates mid-winter ecosystem $\mathrm{CO}_{2}$ production in sub-arctic heath tundra. Climatic Change 50:129-142

Hart SC, Sollins P (1998) Soil carbon and nitrogen pools and processes in an old-growth conifer forest 13 years after trenching. Can J For Res 28:1261-1265

Hanson PJ, Wullschleger SD, Bohlman SA, Todd DE (1993) Seasonal and topographic patterns of forest floor $\mathrm{CO}_{2}$ efflux from an upland oak forest. Tree Physiol 13:1-15

Hanson PJ, Edwards NT, Garten CT, Andrews JA (2000) Separating root and soil microbial contributions to soil respiration: a review of methods and observations. Biogeochemistry 48:115-146

Helal HM, Sauerbeck D (1991) Short-term determination of the actual respiration rate of intact plant roots. In: McMichael BF, Persson H (eds) Plant roots and their environment. Elsevier, London, pp 88-92

Högberg P, Ekblad A (1996) Substrate-induced respiration measured in situ in a C3-plant ecosystem using additions of C4-sucrose. Soil Biol Biochem 28:1131-1138

Högberg P, Nordgren A, Buchmann N, Taylor AFS, Ekblad A, Högberg MN, Nyberg G, Ottosson-Löfvenius M, Read DH (2001) Large-scale forest girdling shows that current photosynthesis drives soil respiration. Nature 411:789-792

Horwath WR, Pregitzer KS, Paul EA (1994) ${ }^{14} \mathrm{C}$ allocation in tree-soil systems. Tree Physiol 14:1163-1176

Houghton RA, Woodwell GM (1989) Global climatic change. Sci Am 260:18-26

Howard PJA (1966) A method for the estimation of carbon dioxide evolved from the surface of soil in the field. Oikos 17:267-271

Hutchinson GL, Mosier AR (1981) Improved soil cover method for field measurements of nitrous oxide fluxes. Soil Sci Soc Am J 45:311-316

Hyvönen R, Ågren GI, Andrén O (1996) Modelling long-term carbon and nitrogen dynamics in an arable soil receiving organic matter. Ecol Appl 6(4):1345-1354

IGBP Terrestrial Carbon Working Group (1998) The terrestrial carbon cycle: implications for the Kyoto protocol. Science 280:1393-1394

Ilvesniemi H, Pumpanen J (1997) SMEARII station for measuring forest ecosystematmosphere relation. In: Haataja J, Vesala T (eds) University of Helsinki Department of Forest Ecology Publications 17. University of Helsinki, Helsinki, pp 30-37Iritz Z, Lindroth A, Gärdenäs A (1997) Open ventilated chamber system for measurements of $\mathrm{H}_{2} \mathrm{O}$ and $\mathrm{CO}_{2}$ fluxes from the soil surface. Soil Technol 10:169-184

Janssens IA (1999) Soil $\mathrm{CO}_{2}$ efflux in a mixed forest ecosystem in the Antwerp Campine region. PhD Thesis, Universiteit Antwerpen (UIA)

Janssens IA, Ceulemans R (1998) Spatial variability in forest soil $\mathrm{CO}_{2}$ efflux assessed with a calibrated soda lime technique. Ecol Lett 1:95-98

Janssens IA, Kowalski AS, Longdoz B, Ceulemans R (2000) Assessing forest soil $\mathrm{CO}_{2}$ efflux: an in situ comparison of four techniques. Tree Physiol 20:23-32

\section{F. Kröner, Heidelberg}


Janssens I, Kowalski A, Ceulemans R (2001) Forest floor $\mathrm{CO}_{2}$ fluxes estimated by eddy covariance and chamber-based model. Agric For Meteorol 106:61-69

Jenkinson DS (1990) The turnover of organic carbon and nitrogen in soil. Philos Trans R Soc Lond B 329:361-368

Jenkinson DS (1991) Model estimates of $\mathrm{CO}_{2}$ emissions from soil in response to global warming. Nature 351:304-306

Joffre R, Ågren GI, Gillon D, Bosatta E (2001) Organic matter quality in ecological studies: theory meets experiment. Oikos 93:451-458

Kanemasu ET, Powers WL, Sij JW (1974) Field chamber measurements of $\mathrm{CO}_{2}$ flux from soil surface. Soil Sci 118:233-237

Keith H, Jacobsen KL, Raison RJ (1997) Effects of soil phosphorus availability, temperature and moisture on soil respiration in Eucalyptus pauciflora forest. Plant Soil 190:127-141

Kirschbaum MUF (1995) The temperature dependence of soil organic matter decomposition, and the effect of global warming on soil organic $\mathrm{C}$ storage. Soil Biol Biochem 27(6):753-760

Kleber M,Stahr K (1995) Soil carbon turnover in subalpine systems and its dependence on climate. In: Zwerver S, van Rompaey RSAR, Kok MTJ, Berk MM (eds) Climate change research: evaluation and policy implications. Elsevier, Amsterdam, pp 561-566

Kutsch WL (1996) Untersuchungen zur Bodenatmung zweier Ackerstandorte im Bereich der Bornhöveder Seenkette. EcoSyst Suppl 16:1-125

Landsberg JJ, Gower ST (1997) Applications of physiological ecology to forest management. Academic Press, San Diego, 354 pp

Lavigne MB, Ryan MG, Anderson DE, Baldocchi DD, Crill PM, Fitzjarrald DR, Goulden ML, Gower ST, Massheder JM, McCaughey JH, Rayment M, Striegl RG (1997) Comparing nocturnal eddy covariance measurements to estimates of ecosystem respiration made by scaling chamber measurements at six coniferous boreal sites. J Geophys Res 102(D24):28,977-28,985

Law B, Baldocchi D and Anthoni P (1999) Below-canopy and soil $\mathrm{CO}_{2}$ fluxes in a ponderosa pine forest. Agric For Meteorol, 94:171-188

Le Dantec V, Epron D, Dufrêne E (1999) Soil $\mathrm{CO}_{2}$ efflux in a beech forest: comparison of two closed dynamic systems. Plant Soil 214:125-132

Li-Cor (1993) LI-6000-09 Soil respiration chamber, instruction manual. Publication no 9311-69. Li-Cor, Inc Lincoln, NE, USA

Lin G, Ehleringer JR, Rygiewicz PT, Johnson MG, Tingey DT (1999) Elevated $\mathrm{CO}_{2}$ and temperature impacts on different components of soil $\mathrm{CO}_{2}$ efflux in Douglas-fir terracosms. Global Change Biol 5:157-168

Lindroth A, Grelle A, Morén AS (1998) Long-term measurements of boreal forest carbon balance reveal large temperature sensitivity. Global Change Biol 4:443-450

Liski J (1997) Carbon storage of forest soils in Finland. University of Helsinki Department of Forest Ecology Publication 16. University of Helsinki, HelsinkiLiski J, Ilvesniemi H, Mäkelä A, Westman CJ (1999) $\mathrm{CO}_{2}$ emissions from soil in response to climate warming are overestimated - the decomposition of old organic matter is tolerant to temperature. Ambio 28:171-174

Lloyd J, Taylor JA (1994) On the temperature dependence of soil respiration. Funct Ecol 8:315-323

Longdoz B, Yernaux M, Aubinet M (2000) Soil $\mathrm{CO}_{2}$ efflux measurements in a mixed forest: impact of chamber disturbances, spatial variability and seasonal evolution. Global Change Biol 6:907-917

Lund CP, Riley WJ, Pierce LL, Field CB (1999) The effects of chamber pressurization on soil-surface $\mathrm{CO}_{2}$ flux and the implications for NEE measurements under elevated $\mathrm{CO}_{2}$. Global Change Biol 5:269-281

\section{F. Kröner, Heidelberg}


Ecological Studies Vol 163, page proofs as of September 11, 2002

Measurement of Soil Respiration

Lundegårdh H (1927) Carbon dioxide evolution of soil and crop growth. Soil Sci 23:417-453

Matteucci G, Dore S, Stivanello S, Rebmann C, Buchmann N (2000) Soil respiration in beech and spruce forest in Europe: trends, controlling factors, annual budgets and implications for the ecosystem carbon balance. In: Schulze E-D (ed) Carbon and nitrogen cycling in European forest ecosystem. Ecological studies 142. Springer, Berlin Heidelberg New York, pp 217-236

Moncrieff JB, Mahli Y, Leuning R (1996) The propagation of errors in long-term measurements of land-atmosphere fluxes of carbon and water. Global Change Biol 2:231-240

Monteith JL, Szeicz G, Yabuki K (1964) Crop photosynthesis and the flux of carbon dioxide below the canopy. J Appl Ecol 1:321-337

Morén AS, Lindroth A (1998) Field measurements of water vapour and carbon dioxide fluxes - chamber system and climatic monitoring by an automatic station. Report 4. Department for Production Ecology, Faculty of Forestry, SLU, Uppsala, Sweden

Nay SM, Mattson KG, Bormann BT (1994) Biases of chamber methods for measuring soil $\mathrm{CO}_{2}$ efflux demonstrated with a laboratory apparatus. Ecology 75(8):2460-2463

Nakane K, Kohno T, Horikoshi T (1996) Root respiration rate before and just after clearfelling in a mauture, deciduous, broad-leaved forest. Ecol Res 11:111-119

Norman JM, Garcia R, Verma SB (1992) Soil surface $\mathrm{CO}_{2}$ fluxes and the carbon budget of a grassland. J Geophys Res 97:18845-18853

Norman JM, Kucharik CJ, Gower ST, Baldocchi DD, Crill PM, Rayment M, Savage K, Striegl RG (1997) A comparison of six methods for measuring soil-surface carbon dioxide fluxes. J Geophys Res 102:28771-28777

Oechel WC, Vourlitis G, Hastings SJ (1997) Cold season $\mathrm{CO}_{2}$ emission from arctic soils. Global Biogeochem Cycles 11:163-172

Parkinson KJ (1981) An improved method for measuring soil respiration in the field. J Appl Ecol 18:221-228

Persson T, Lundkvist H, Wirén A, Hyvönen R, Wessén B (1989) Effects of acidification and liming on carbon and nitrogen mineralization and soil organisms in mor humus. Water Air Soil Pollut 44:77-96

Peterjohn WT, Melillo JM, Steudler PA, Newkirk KM (1994) Responses of trace gas fluxes and $\mathrm{N}$ availability to experimentally elevated soil temperatures. Ecol Appl 4(3):617-625

Pumpanen J, Ilvesniemi H, Keronen P, Nissinen A, Pohja T, Vesala T, Hari P (2001) An open chamber system for measuring soil surface $\mathrm{CO}_{2}$ efflux: analysis of error sources related to the chamber system. J Geophys Res Atmos 106(D8):7985-7992

Qi J, Marshall JD, Mattson KG (1994) High soil carbon dioxide concentrations inhibit root respiration of Douglas fir. New Phytol 128:435-442

Raich JW, Schlesinger WH (1992) The global carbon dioxide flux in soil respiration and its relationship to vegetation and climate. Tellus 44B:81-99

Rayment MB (2000) Investigating the role of soils in terrestrial carbon balance - harmonising methods for measuring soil $\mathrm{CO}_{2}$ efflux. LESC Exploratory workshop, Edinburgh, 6-8 April. European Science Foundation. http://www.esf.org/generic/163/2073 aappitem5.1a.pdf

Rayment MB, Jarvis PG (1997) An improved open chamber system for measuring soil $\mathrm{CO}_{2}$ effluxes in the field. J Geophys Res 102(D24):28,779-28,784

Rochette P, Ellert B, Gregorich EG, Desjardins RL, Pattey E, Lessard R, Johnson BG (1997) Description of a dynamic closed chamber for measuring soil respiration and its comparison with other techniques. Can J Soil Sci 77:195-203

Ryan MG, Hubbard RM, Pongracic S, Raison RJ, McMurtrie RE (1996) Foliage, fine-root, woody-tissue and stand respiration in Pinus radiata in relation to nitrogen status. Tree Physiol 16:333-343

\section{F. Kröner, Heidelberg}


Ryan MG, Lavigne MB, Gower ST (1997) Annual carbon cost of autotrophic respiration in boreal forest ecosystems in relation to species and climate. J Geophys Res 102 (D24):28.871-28.883

Schimel DS (1995) Terrestrial ecosystems and the carbon cycle. Global Change Biol 1:77-91

_imùnek J, Suarez DL (1993a) Modelling of carbon dioxide transport and production in soil. 1. Model development. Water Resour Res 29(2):487-497

_imùnek J, Suarez DL (1993b) Modelling of carbon dioxide transport and production in soil. 2. Parameter selection, sensitivity analysis, and comparison of model predictions to field data. Water Resour Res 29(2):499-513

Schwartzkopf SH (1978) An open chamber technique for the measurement of carbon dioxide evolution from soils. Ecology 59:1062-1068

Swinnen J, van Veen JA, Merckx R (1994) Rhizosphere carbon fluxes in field-grown spring wheat: model calculations based on $14 \mathrm{C}$ partitioning after pulse-labelling. Soil Biol Biochem 26:171-182

Tate KR, Ross DJ, O’Brien BJ, Kelliher FM (1993) Carbon storage and turnover, and respiratory activity, in the litter and soil of an old-growth southern beech (Nothofagus) forest. Soil Biol Biochem 25:1601-1612

Thierron V, Laudelout $\mathrm{H}$ (1996) Contribution of root respiration to total $\mathrm{CO}_{2}$ efflux from the soil of a deciduous forest. Can J For Res 26:1142-1148

Trumbore SE, Chadwick OA, Amundson R (1996) Rapid exchange between soil carbon and atmospheric carbon dioxide driven by temperature change. Science 272(5260): 393-396

Webb EK, Pearman GI, Leuning R (1980) Correction of flux measurements for density effects due to heat and water vapour transfer. Q J R Meteorol 106:85-100

Widén B, Lindroth A (2002) A calibration system for soil $\mathrm{CO}_{2}$ efflux chamber systems: description and application. Soil Sci Soc Am J (in press)

Widén B, Majdi H (2000) Soil CO2 efflux and root respiration at three sites in a mixed pine and spruce forest: seasonal and diurnal variation. Can J For Res 31:786-796

Witkamp M, Frank ML (1969) Evolution of $\mathrm{CO}_{2}$ from litter, humus and subsoil of a pine stand. Pedobiologia 9:358-365

Zimov SA, Davidov SP, Voropaev V, Prosiannikov SF, Semiletov IP, Chapin MC, Chapin FS (1996) Siberian $\mathrm{CO}_{2}$ efflux in winter as a $\mathrm{CO}_{2}$ source and cause of seasonality in atmospheric $\mathrm{CO}_{2}$. Climatic Change 33:111-120

\section{F. Kröner, Heidelberg}

